\title{
Familial case of Darier's disease: A rare genodermatosis
}

\author{
Mohammad Kamrul Ahsan ${ }^{1 *}$, M Moniruzzaman khan², Mir Nazrul Islam³
}

\begin{abstract}
:
Darier's disease, also known as keratosis follicularis is a rare autosomal dominant inherited genodermatosis characterized by abnormal keratinization. A 39-year old non-diabetic, normotensive man presented to dermatology OPD with discretely distributed dark brown greasy, warty, malodorous, hyperkeratotic papules over his whole body for last 15 years. He has two young daughters and both has started initial stage of similar lesions for last 6 months. Characteristic $v$-shaped nicking at the tip of the nails with longitudinal red \& white ridges were seen. Nails at the distal ends were broken. Biopsy of skin for histopathological examination showed more specific and confirmatory 'corps ronds and grains'. This article reports a case of familial darier's disease. Good improvement was noticed after acitretin therapy.
\end{abstract}

Key words : Darier's disease, Autosomal dominant, Genodermatosis, Acitretin

\section{Introduction}

Darier's disease is a genetic, inherited skin disorder characterized by brown keratotic papules that tend to coalesce into patches in a seborrheic distribution ${ }^{1}$. Early lesions are small, firm papules, later covered with a greasy, gray-brown crust. Over years, the papules grow and may fuse to form malodorous, papillomatous, vegetating growths. Although this is a genetically transmitted disease, according to a larger series about $47 \%$ had no clear family history presumably because of incomplete penetrance and variable expressivity. The disease is caused by mutations in the ATP 2 A2 gene, which encodes the sarco/endoplasmic reticulum $\mathrm{Ca}^{2+}$ ATPase isoform ${ }^{2,3}$. The prevalence of this disorder in population is 1:100000. The sex incidence is equal, although the males appear to be more severely affected than females ${ }^{4,5}$. Here we are reporting a case of familial Darier's disease affecting father and daughters.

\section{Case report}

A 39 year old man presented with eruptions on the body for 15 years, with malodor from same areas for 5-6 years and has been under topical and herbal medications intermittently but with no improvement. Initially, he developed pruritic dark brown, discrete papules with a greasy texture distributed over the face, neck and chest (Fig-1). Gradually the lesions spreaded all over the body forming warty, vegetating growths

1. Associate professor, Dept. of Dermatology, Ibrahim Medical College and BIRDEM General Hospital.

2. Assistant professor, Dept. of Dermatology, Ibrahim Medical College and BIRDEM General Hospital.

3. Professor, Dept. of Dermatology, Ibrahim Medical College and BIRDEM General Hospital.

\footnotetext{
*Corresponding Author:

Dr. Mohammad Kamrul Ahsan, MBBS, MD (Derma)

Associate Professor, Dept. of Dermatology

Ibrahim Medical College and BIRDEM General Hospital

Shahbagh, Dhaka - 1000, Bangladesh.

Cell phone: +8801703003898

Email: dr.kamrul1966@gmail.com
}

and infected during summer. His nails showed v-shaped triangular nicking of the free edges with longitudinal alternating white and red nail lines (Fig-2). There were no associated systemic complaints. He has two young daughters ( 6 and 4 years respectively) and both has started initial stage of similar lesions for last 6 months (Fig-3). His hair and mucous membrane examinations were normal.
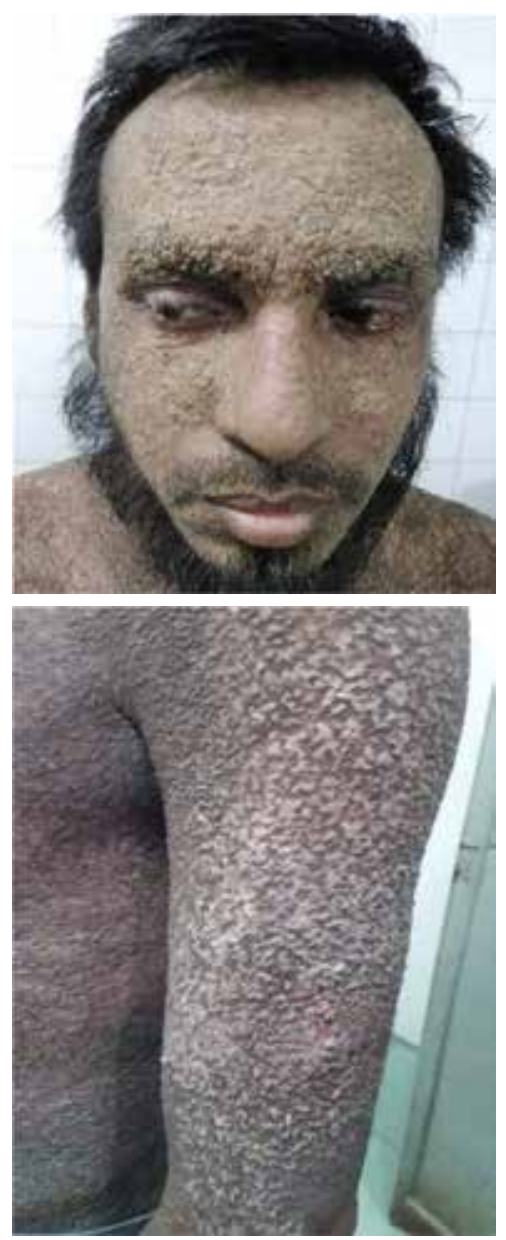

Fig 1: showing multiple dark brown, greasy keratotic papular lesions on face, trunk and upper limb, some are coalescing into plaques on face. 
Bangladesh Crit Care J March 2020; 8 (1): 55-57

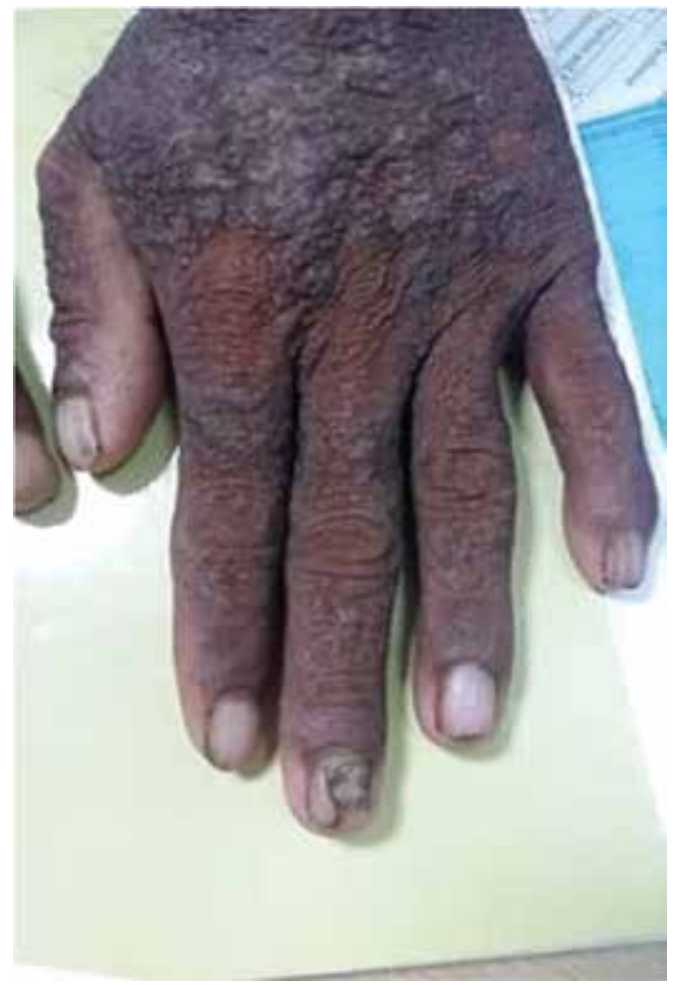

Fig 2: Nail involvement showing v-shaped notches with fragility and longitudinal red and white lines.

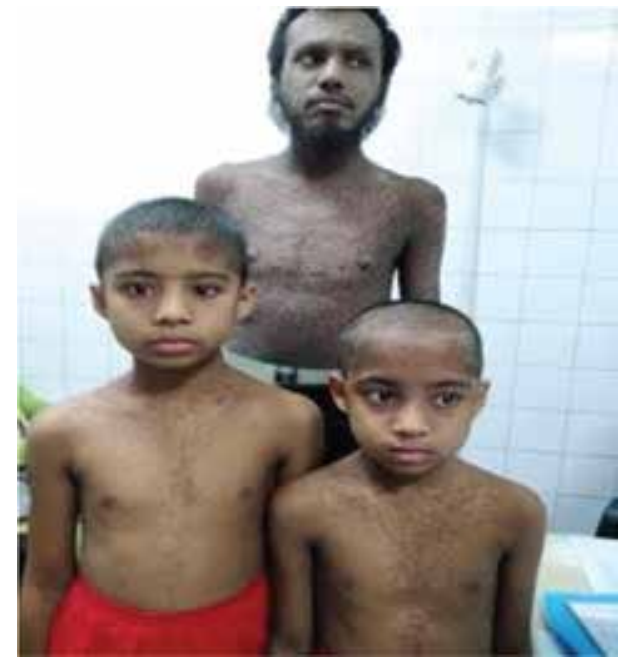

Fig 3: Both the daughters showing early keratotic, papular lesions on the trunk.

Considering signs and symptoms, we considered differential diagnosis of Darier's disease, Hailey-Hailey disease, Bazex syndrome, ichthyosiform dermatosis, Langerhans cell histiocytosis and severe atopic dermatitis. General examination and other systemic examination revealed no abnormality. His CBC, LFT, blood sugar, renal, thyroid all were within normal limit. Histological examination showed suprabasal clefts in the epithelium with acantholytic and dyskeratotic cells represented by "corps ronds and grains".
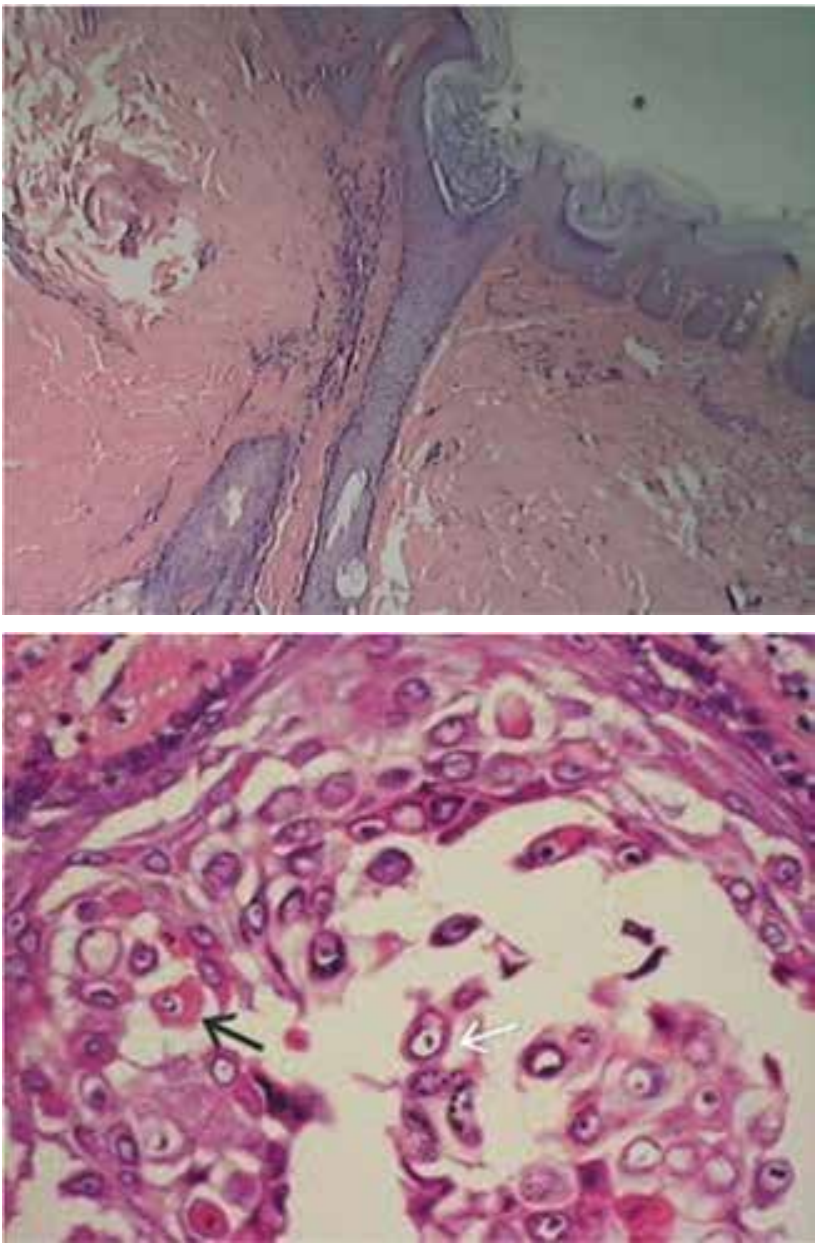

Fig 4: Histopathological features showing focal suprabasal clefting and dyskeratotic cells with "corps and ronds" and grains in epidermis (Hematoxylin -eosin stain)

Biopsy report is confirmatory of Darier's disease. So, our final diagnosis is familial Darier's disease. Patient was treated with systemic retinoid(Tab acitretin $25 \mathrm{mg}$ /daily), antihistamine, topical moisturizer and steroid cream. After 1 month of treatment patient came for follow up. Good improvement was noticed.

\section{Discussion}

Darier's disease is a rare keratinization disorder with skin involvement and relatively subtle oral mucosal lesions. In Darier's disease abnormal dissolution of desmosomal plaque proteins is seen in electron microscopy. Calcium ion $\left(\mathrm{ca}^{++}\right)$ dependent cell-cell adhesion molecules (epithelial cadherins) are greatly reduced on the acantholytic cells of patients of Darier's disease contributing to acantholysis ${ }^{6}$.

Darier's disease is usually manifested during childhood or adolescence. But the full picture is seen in the $4-5^{\text {th }}$ decade of life and our case also belongs to this category. Numerous erythematous pruritic small, firm papules appear first on seborrheic areas, later on become grayish brown, ulcerates and gets crusted. Foul odor may also be present as a result of secondary infection. Palmer and planter keratosis may be 
present with nail changes ${ }^{7}$. The frequency of oral lesions range from $15 \%$ to $50 \%$ and is present on the palate showing a cobblestone appearance ${ }^{8,9}$. The present case showed skin lesions and nail abnormality without mucosal involvement. Precipitating factors were heat and humidity, mechanical trauma like friction, sunlight and secondary bacterial infections. In the literature, associated anomalies have been described including mental retardation and psychosis ${ }^{10}$. In our patients such anomalies were absent.

Darier's disease is more associated with cosmetic and esthetic than functional implications since this is a benign dermatosis. But depending on severity of the disease, the emotional status may be damaged by esthetic reasons. The systemic treatment of the Darier's disease is symptomatic. The lesions relapse because of hereditary etiopathogenesis, especially in patients with severe and generalized form of disease.

\section{Conclusion}

Most patients with severe Darier's disease should receive genetic counseling, including information of inherited condition and risk of transmission to offspring. Biopsy is necessary to arrive at definitive diagnosis. Dental and psychiatric opinion should follow in severe cases to prevent possible complications. So multidisciplinary approach is needed for better management.

\section{References:}

1. James WD, Elston DM, Treat JR, Neuhaus IM. Andrews' diseases of the skin. $13^{\text {th }}$ ed. Elsevier, 2020,pp.572

2. Sakuntabhai A, Burge S, Monk S, Hovnanian A. Spectrum of novel ATP2A2 mutations in patients with Darier's disease. Hum Mol Genet 1999;8:1611-1619.

3. Sakuntabhi A, Ruiz-Perez V, Carter S. Mutations in ATP2A2, encoding a ca2+ pump, cause Darier disease, Nature Genetics,1999;21:271-277.

4. Cooper SM, Burge SM. Darier's disease: epidemiology, pathophysiology, and management. Am J clin Dermatol 2003;4,97-105.

5. Burge SM, Wilkinson JD. Darier-white disease: a review of the clinical features in 163 patients, J Am Acad Dermatol 1992;27: 40-50.

6. Burge S. Darier's disease - the clinical features and pathogenesis. Clin Exp Dermatol 1994;19:193-205.

7. Zaias N, Ackerman AB. The nail in Darier-White disease. Arch Dermatol. 1973;107(2):193-9

8. Jalil AA, Zain RB, Van der Waal I, Darier disease: a case report, Br $\mathrm{J}$ oral and maxillofac surg 2005;43: 336-338.

9. Ferris T, Lamey PG, Rennie JS. Darier's disease: oral features and genetic aspects. Br dental J 1990;168:71-73.

10. Dodium-Gad R, Lerner M, Rozenman D. Learning disabilities in Darier's disease patients. J Eur Acad Dermatol Venereol 2014;28:314- 9 . 